\title{
Knowledge in Practice: Documenting Rancher Local Knowledge in Northwest Colorado
}

\author{
Corrine Noel Knapp ${ }^{1}$ and Maria E. Fernandez-Gimenez ${ }^{2}$ \\ Authors are ${ }^{1}$ Graduate student and ${ }^{2}$ Associate Professor, Department of Forest, Rangeland and Watershed Stewardship, 1472 Campus Delivery, \\ Colorado State University, Fort Collins, CO 80523-1472, USA.
}

\begin{abstract}
For more than 150 years, ranchers in the West have gained insight about natural systems through daily interaction and management of landscapes, but this knowledge has never been systematically documented and analyzed. We interviewed 26 ranchers from a single watershed to understand how ranchers acquire their knowledge, document what they know about rangeland ecosystems, and explore how this knowledge varies within the ranching community. This exploratory study offers insight into the types of knowledge ranchers possess without attempting to survey all rancher knowledge or ascribe this set of knowledge to all ranchers. We identified three major knowledge categories in interviews: active knowledge applied to management decisions, embedded knowledge from living in place, and integrative knowledge that links ecological, economic, and social aspects of rangeland systems. We found rancher knowledge complemented scientific knowledge in its ability to provide site-specific information on management practices and ecological responses, and insight regarding potential indicators of rangeland health. Knowledge varies widely within the ranching community, and knowledgeable ranchers are readily identified through community referrals. Ranchers gained their knowledge primarily through experience and social interactions, and this knowledge is an untapped source of context-specific information. We did find that economic constraints, social norms, and proximity to the system might limit application of knowledge to practice. There is also a danger that this accumulated and dynamic knowledge base will be lost over the next generation, as many family ranches are sold to new ranchers or for nonranching uses. Based on our findings, we propose that more dialogue within ranching communities and between ranchers and scientists may lead to more sustainable land management practices and effective outreach efforts, and could expand and strengthen the informal social networks through which much rancher knowledge is shared and on which the social sustainability of ranching communities depends.
\end{abstract}

\section{Resumen}

Durante más de 150 años, los productores del oeste de los Estados Unidos han acumulado conocimiento sobre los sistemas naturales a través de la interacción diaria con los paisajes que manejan. Sin embargo, esta sabiduría nunca ha sido documentada y analizada sistemáticamente. Entrevistamos a 26 productores de una única cuenca hidrográfica para comprender como adquieren conocimientos, documentar lo que saben sobre los ecosistemas de pastizales naturales, y explorar como esta sabiduría varía dentro de la comunidad de productores. Este estudio exploratorio provee una comprensión más profunda de los tipos de conocimiento que poseen los productores, sin embargo no procura describir la totalidad del conocimiento poseída por los mismos ni atribuir este conjunto de conocimientos a todos los productores. Nuestras entrevistas identificaron tres categorías principales de conocimiento: conocimiento activo aplicado a las decisiones de manejo, conocimiento proveniente de vivir en un lugar, y conocimiento integrador que vincula aspectos ecológicos, económicos, y sociales de los sistemas de pastizales naturales. Encontramos que el conocimiento de los productores complementa el conocimiento científico por su capacidad para proveer información específica sobre las prácticas de manejo y las respuestas ecológicas de un determinado sitio, y perspectivas sobre potenciales indicadores del estado de salud de los pastizales. El nivel de conocimiento varía ampliamente dentro de la comunidad de productores, y aquellos que poseen mayores conocimientos son fácilmente identificables por referencias provistas por pares de la comunidad. Los productores adquieren conocimiento a través de la experiencia y las interacciones sociales, no obstante, encontramos que limitaciones económicas, normas sociales y la proximidad al sistema podrían limitar la puesta en práctica de dicho conocimiento. El conocimiento de los productores es una fuente de información contexto-especifica sin explorar, sin embargo, existe el peligro de que esta base de conocimiento dinámico acumulado se pierda en el transcurso la próxima generación, dado que muchos establecimientos familiares se están vendiendo a nuevos productores o están siendo utilizadas para usos no productivos. Sobre la base de nuestros resultados, proponemos que mayor diálogo dentro de la comunidad de productores y entre productores e investigadores podría redundar en prácticas de manejo de la tierra mas sustentables, en mayor efectividad en los esfuerzos de transferencia y podría expandir y fortalecer las redes sociales informales a través de las cuales se transmite el conocimiento de los productores y de las que depende la sustentabilidad de las comunidades de productores.

Key Words: adoption of innovations, knowledge networks, local knowledge, management, ranchers, rangeland health, semistructured interviews

Research was funded by the Colorado Agricultural Experiment Station and a Natural Resources Conservation Service Conservation Innovation Grant.

Correspondence: Maria Fernandez-Gimenez, Associate Professor, Department of Forest, Rangeland and Watershed Stewardship, 1472 Campus Delivery, Colorado State University, Fort Collins, CO 80523-1472, USA. Email: Maria.Fernandez-Gimenez@colostate.edu

Manuscript received 23 July 2008; manuscript accepted 3 September 2009.

\section{INTRODUCTION}

The United States has over 770 million acres of rangelands (US Forest Service 2008); however, these systems often lack sitespecific research or long-term ecological monitoring to understand ecosystem processes and inform best management 
practices (West 2003). Rancher knowledge may provide insight into ecosystem processes, sustainable management practices, and interactions between human and natural communities (Knapp and Fernandez-Gimenez 2008). Despite this potential, few studies have explored rancher knowledge of rangeland ecosystems or how their knowledge may contribute to greater understanding and improved management of western rangelands. Integrating rancher knowledge may facilitate better communication between ranchers and researchers, increase adoption of range research by ranchers (Kelly 2001; Johnson et al. 2003), and inform collaborative natural resource management (Daniels and Walker 2001). If current trends of rangeland transformation for exurban development, recreation, and oil and gas extraction (Heinz Center 2002) continue, local rancher knowledge may be lost (Moore 1996; Spencer 2004). It is critical that we understand the substance of rancher knowledge in order to assess its utility and explore ways to conserve it in practice.

In this paper we adopt Agrawal's (1995) definition of local knowledge as knowledge "integrally linked with the lives of people, always produced in dynamic interactions among humans and between humans and nature, and constantly changing" (Agrawal 1995). Local knowledge is knowledge gained by daily contact with the natural world and ecological processes. This knowledge is not a pooled resource with constant attributes; instead it varies within each community and is always in flux (Davis and Wagner 2003; Fazey et al. 2006). Since pioneering studies in the late 1970s, research on local knowledge has focused on indigenous communities and encompassed local management practices in agriculture (Conklin 1954; Marten 1986; Thrupp 1989; DeWalt 1994), fisheries (Mackinson 2001), whaling (Huntington 2000), and pastoral societies (Netting 1981; Niamir 1995; Bollig and Schulte 1999; Kuznar 1999; Fernandez-Gimenez 2000; Oba and Kaitira 2005).

Research on local knowledge of grazing and rangeland systems has focused on pastoralist communities in developing countries with long-established grazing practices (Niamir 1995; Bollig and Schulte 1999; Fernandez-Gimenez 2000; Spencer 2004; Roba and Oba 2009). Pastoralists can be defined as people whose primary economic activity is based on raising livestock (Merriam-Webster Online Dictionary 2008). Pastoralists depend on the land for their livelihoods and accumulate knowledge of ecosystem processes through experience (Niamir 1995) and cultural traditions embodied in myth and story (Conklin 1954; Colding and Folke 2001), which are reflected in their institutional arrangements (Agrawal 1993). Research has found that local producers have knowledge about the range of variation in vegetation under different management and climactic scenarios (DeBoer and Prins 1989), indicators of change (Reed and Dougill 2002; Oba and Kaitira 2005), and long-term plant community dynamics (Bollig and Schulte 1999; Davis 2005). Pastoralists make decisions based on a knowledge of the landscapes they manage, including knowledge of the physical environment, social interactions, economic considerations, and local beliefs and values (Pierotti and Wildcat 2000; Carr 2004; Spencer 2004). Pastoralist knowledge has been used to inform policy (Agrawal 1993; Fernandez-Gimenez 2000; Desta and Coppock 2004), develop meaningful educational resources (Arnold and Fernandez-Gimenez 2003), design sustainable management practices (Hudak 1999), and provide insight for research and development projects (Kroll and Kruger 1998).

Despite the interest in and research on pastoralist communities in developing countries, currently only a handful of studies examine rancher knowledge in developed countries. Existing studies have investigated farmer and rancher knowledge of pasture cultivars (Belgrave et al. 1990) and native grasses (Garden et al. 2000), explored sense of place in Australia (Gill 2005), compared indigenous and pastoralist knowledge in Australia (Read 1996; Strang 1997), and documented farmer use of pasture herbs in Denmark (Smidt and Brimer 2005). In the United States, formal research on rancher ecological knowledge has been minimal and has focused primarily on decision making related to adoption of new techniques (Rowan et al. 1994; Coppock and Birkenfeld 1999; Kreuter et al. 2001; Didier and Brunson 2004; Kreuter et al. 2008), ranching motivations (Grisgby 1980; Peterson and Coppock 2001; Rowe et al. 2001), and rancher attitudes and perceptions (Saltiel and Irby 1998; Conley et al. 2007). It has been demonstrated that ranchers access information from different sources and in different manners than agency employees (Fernandez-Gimenez et al. 2005). Research has highlighted the importance of the social context of decision making, especially in the development and negotiation of norms and practices among ranching neighbors (Ellickson 1991; Yung and Belsky 2007). Although local historical museums and community groups have begun to compile oral histories of ranchers (C. Lombardo, personal communication, January 2008), we are not aware of any systematic studies that document and analyze rancher ecological and management knowledge in the western United States.

This study focuses on rancher knowledge in a single watershed and its surroundings in northwest Colorado. Our primary objectives in this exploratory, place-based study were to 1) learn how ranchers in this location acquire local knowledge, 2) document and analyze the substance and range of that knowledge, and 3) analyze the distribution and variation of knowledge among ranchers within a specific watershed. As the first study of its kind in the United States, we also developed and tested a methodology for eliciting, documenting, and analyzing rancher local ecological knowledge.

\section{STUDY SITE}

The Elkhead watershed straddles Routt and Moffat counties in northwestern Colorado, USA, and lies north of Highway 40 between the small cities of Steamboat Springs and Craig. It is approximately 60700 ha in size and spans elevations from $1800 \mathrm{~m}$ to almost $3000 \mathrm{~m}$. The Elkhead region is semiarid, with mean annual precipitation for Hayden of $43 \mathrm{~cm}$ and yearly average high temperatures of $14.4^{\circ} \mathrm{C}$ and average lows of $-2.7^{\circ} \mathrm{C}$, although winters can be extreme (High Plains Regional Climate Center 2008). Private land dominates the lower elevations, where sagebrush steppe is the primary vegetation type ( $75 \%$ of watershed), whereas Routt National Forest encompasses the higher elevations and is composed of sagebrush steppe, aspen/tall forb, and evergreen communities 
(25\% of watershed). Historically, heavy livestock use has contributed to both the early seral condition of grassland and shrublands on the Forest and the lower fuel load, which has led to changed fire regimes (US Forest Service 2009). Although long-term monitoring plots exist on Forest Service lands within the watershed, there are no known ecological studies of this watershed, and very few studies of the region (Mannier and Hobbs 2006) to give scientific insight into rangeland status and change over time.

According to the 2008 census, there are 2199 residents of the region encompassing the Elkhead watershed. Although agriculture is a historical mainstay of the economy, only $2 \%$ of residents work in agriculture, fishing, or forestry, and half of the census respondents included in the agriculture sector have offfarm employment. Although agriculture remains a dominant land use, it is a decreasing contributor to the local economy. In the past five years, Routt County has seen a growth rate of $9.6 \%$, and Moffat County has grown 3.8\% (US Census Bureau 2008). In Routt County total land values have increased $37 \%$ during a two-year time period from 2004 to 2006 (T. Segler, personal communication, 15 January 2008). It is increasingly challenging to operate successful ranches in this area, and the transition from ranching to ex-urban development, and the concern surrounding it, have been marked by a series of articles in the local newspaper (Metz 2004). Ranchers in this area represent those who have survived in the face of rising land prices, lower profit margins, and increasing recreational and amenity buyers (Rowe et al. 2001). Their ability to adapt to changed conditions may separate this population from a ranching community not facing these pressures.

We chose to focus the interviews within the Elkhead watershed because it has a mix of large and small landowners, has an active ranching community, is a manageable size, and is relatively unfragmented. Regional interviewing also made it easier to compile and compare knowledge claims, gain a representative sample of local knowledge, and analyze knowledge of similar vegetation communities.

\section{METHODS}

The target population for interviews was ranchers who reside, use, or manage land within or in proximity to the focus watershed in northwestern Colorado. We identified landowners in the watershed through a search of county ownership records and included as potential interviewees all landowners in the watershed with more than 100 acres of deeded land who had at least five years of experience in this watershed. In addition, we asked current ranchers and community members to recommend knowledgeable people within their community. This provided us with a list of current and former ranchers close to the watershed, as well as giving us insight into who the community identified as knowledgeable. Once potential informants were identified, we contacted them with a letter and a follow-up phone call to invite their participation in the project and to confirm they were actively managing the acres that they owned in the watershed. After these initial contacts, we also held a community meeting to introduce residents to the project and encourage their participation.
We completed 26 semistructured interviews and 11 field interviews with ranchers within or close to the Elkhead watershed. The semistructured interview is the most standard technique for gathering local and indigenous knowledge (Huntington 1997). The semistructured interviews allowed us to ask the same questions of each rancher so that comparisons between interviews could be made. The field interviews, based on a loose series of questions, were open-ended, providing an opportunity for open dialogue regarding management practices and knowledge of rangelands (Whyte 1982; Morris 2006). Because local knowledge is often tacit (Fazey et al. 2006), the field component was helpful for connecting knowledge to specific places and practices. The two-tiered interview process also helped to build rapport between researchers and ranchers and allowed for more informative interviews.

\section{Participants}

We were able to interview a third of the ranchers in the watershed, including 10 women and 16 men, most in their midfifties to early sixties. Sixteen were currently engaged in active management, while 10 had either retired or left the ranch. Most of the ranchers (20) had grown up on a ranch, and many (14) had been in ranching for more than two generations. Nine of the ranchers had gained their knowledge through experience only, six had some formal education, and 11 had finished related undergraduate degrees, including animal science, range ecology, and agricultural economics. Three of those interviewed were primarily sheep ranchers, the other 19 were primarily cattle ranchers, and four raised wheat and cattle. Of the ranchers interviewed, there were five small (640-1000 acres), five medium (1 001-5 000 acres), and two large (5 00110000 acres) landowners and four who owned or leased over 10000 acres. To gain wider perspective on the region, we also completed four interviews with agency staff members, and one with a wheat farmer, for a total of 32 participants.

We were able to interview a cross section of ranchers by ranch size, education level, and duration in the watershed and believe our interviews are representative of the watershed as a whole. No one refused to be interviewed, and therefore the sample was drawn from the population of potential interviewees based on ranchers' availability to interview during researcher field visits. Interviews were conducted over a yearlong period, with most taking place in spring and summer of 2007. Although we had no preconceived number of interviews to conduct, we stopped interviewing when we felt little or no new information was being collected with additional interviews (Neuman 2003).

\section{Analysis}

All of the interviews were audio recorded, transcribed, and coded using NVIVO data analysis software (NVIVO 19992000). Coding is a commonly used qualitative analysis technique that allows researchers to explore, understand, and compare interviews by tracking specific themes (Neuman 2003). We developed a list of potential codes, or themes, to track through the interviews based on our research questions. As we read through each interview, we coded based on the original set and added additional codes as emergent knowledge categories were discovered. Once initial coding was completed, 
we reviewed the quotations related to each theme to assess whether they reflected the same type of knowledge. The analysis included both quantitative and qualitative assessments of the knowledge claims. For the quantitative measure, we tallied both the number of coded passages regarding different themes or subjects and the number of ranchers who addressed each theme. In addition, we examined the substance of the claims to understand the nature of rancher knowledge and the consensus between ranchers.

\section{RESULTS}

Our results describe the total pool of knowledge held by ranchers interviewed in this watershed, but it is important to understand that each individual reflects a different segment of the total knowledge pool. Thus, our findings identify and describe the general types of knowledge held by ranchers; however, they may not encompass all the types of knowledge that ranchers hold, nor do we suggest that all ranchers possess the types of knowledge discussed in this paper.

Interviews with ranchers revealed three primary categories of rancher knowledge: active knowledge gained through management of natural systems for production, embedded knowledge gained through living in a particular place, and integrative knowledge of the interconnections between social, ecological, and economic factors. In the following sections, we describe and give examples of these three types of knowledge.

\section{Active Knowledge: Management of Natural Systems for Productivity}

As an integral part of their livelihoods, ranchers manage ecosystems for domestic livestock production. In the following sections, we illustrate how ranchers synthesize knowledge of ecological principles to run successful livestock operations and maintain the productivity of the land.

Plant Growth and Reproduction. Ranchers spoke of the need to manage plant growth and reproduction to maintain forage resources. Half of ranchers interviewed spoke about the importance of managing the timing of grazing and allowing for plants to recover after a grazing period to maintain viable grass populations. As an example, one rancher stated, "Part of the range management plan was not to put cattle in until September when the grass was mature and heading out and there was a chance that the cattle would scatter the seed and trap it in the ground and we ended up with some very good pastures."

Diversity and Heterogeneity of Vegetation. Ranchers described how landscape diversity and heterogeneity were critical to maintaining healthy and productive landscapes. Many ranchers, especially sheep ranchers who rely on seasonal ranges, described the importance of diversity on a landscape scale to provide for the nutritional needs of livestock. As one suggested, "You only need a bite [of some of the forbs], but they need that bite and if you destroy that bite a day, then without that plant they [the livestock] won't do as well." Many ranchers were also interested in increasing the productivity of the systems they manage and used some type of shrub control, either mechan- ical, chemical, or fire, to increase grass production. While interested in increasing productivity, ranchers simultaneously noted the importance of landscape heterogeneity and described management actions to increase heterogeneity, such as using a mosaic form of brush treatment, giving the land time to recover post-treatment, and leaving some standing dead shrubs to capture snow and prevent wind erosion. Several ranchers also perceived negative effects of shrub treatments on water infiltration, erosion, and herbaceous species diversity.

Animal Behavior. Ranchers had intimate knowledge of domestic livestock behaviors, their impacts, and how these behaviors can be influenced with management. Ranchers described how livestock do not use all parts of a landscape equally and spend the most time in riparian areas where shade and water are available. As one rancher stated, "The cows hang out right down in the trees by the river. They get up early and walk around and then lie around till noon or so and go out and eat a little bit and then go back to the shade." In response to these behaviors, ranchers used management practices such as cross-fencing, water developments, herding, and salting to improve livestock distribution and limit negative impacts on riparian areas.

Understanding Disturbance and Environmental Stress. Ranchers manage landscapes that experience a variety of disturbances and stresses and described how landscapes react to these events. Ranchers see certain disturbances and stressors, such as drought, as part of the natural variation and function of rangeland ecosystems. As one rancher stated, "When I was younger I thought it [drought] was a problem, but now I have realized that drought is a part of this country." Eighty-one percent of the ranchers interviewed talked about the impact of drought on specific places.

Seventy-five percent of the ranchers identified heavy grazing as a disturbance that creates vegetation change. Effects of heavy grazing mentioned by ranchers included lowered productivity and diversity, decreased forage quality, invasion of non-natives, erosion, and diminished riparian health. As one rancher stated succinctly, "If you have a lot of mouths hitting it hard and not having anything else to pick from then yes, it is going to degrade the land." Ranchers differentiate between the type of disturbance linked with livestock and that caused by wildlife grazing, as wildlife are more challenging to control. One rancher explained, "the problem with wildlife is that you can't control what they do and you can't control the numbers and sometimes you have too many." Recreation, primarily hunting, is cited as a diffuse disturbance that creates erosion, affects wildlife movements, and facilitates transport and spread of weedy species.

Vegetation Change. Ranchers described basic processes of vegetation change and the types of species that colonize disturbed areas. One rancher explained, "most of the forbs come back pretty well and the grasses, but it is difficult to get the brush back in." Ranchers also explained how some noninvasive ruderal species work as placeholders for recovering systems. Ranchers described how annual weeds are often the first species to colonize a disturbed area, but also observed that perennial native species will eventually outcompete them. As one rancher said, "You get cheatgrass and some weedy forbs at 
first, but then the grasses come back and take the forbs out." Detailed descriptions of rancher knowledge of vegetation change are included in another manuscript discussing stateand-transition models (Knapp and Fernandez-Gimenez 2009).

Indicators of System Health. Ranchers identified several indicators of land health including plant diversity, productivity, canopy cover, amount of bare ground, lack of non-native and invasive species, absence of erosion, and in riparian areas, multi-aged tree stands and bank stability. Ranchers used these indicators to understand rangeland health trends, and decide when to move cattle and adjust cattle numbers. One rancher stated, "You see heads of grass here and there and if you look in the sagebrush area and see bare ground, then I think you are using it too heavy." Ranchers continually assess and balance multiple indicators to make management decisions, making it challenging for them to define exactly how they use this information when making a decision.

\section{Embedded Knowledge: Learning by Living in a Specific Place}

Ranchers also possess embedded knowledge, which is knowledge that comes from living on the land and observing natural processes. This knowledge includes limited understanding of cycles that are longer than a human lifetime, such as erosion processes, changes in hydrology, climate change, and ecosystem resilience. Ranchers throughout the Elkhead drainage described how regional soils have a propensity to slough off following heavy rain or snowmelt events. As one rancher stated, "The whole country will slough and there are cracks and it is very unstable and it happens often." In the course of their time on the land, ranchers perceived change in watershed health and function, including bank stability and flow rates. Ranchers identified how management can affect bank stability and said things like, "The least healthy part of the creek is through the dry-land hay because there is nothing holding the banks. It isn't really head cutting but it is slumping."

All of the ranchers perceived that they were experiencing an extended drought, but disagreed about whether it was cyclical or represented long-term unidirectional climate change. One rancher stated, "I call it climate change," while another said, "I think it is cyclical ... whether it is permanent or not I don't know." Ranchers see these systems through good years and poor years, and the shifting character of the land leaves many ranchers with an overall sense of its resilience. When ranchers spoke of resilience, they were suggesting that although the landscape experienced disturbance, it did not lose its inherent productivity or change its fundamental processes. As one rancher expressed, "the most amazing thing about the big picture is how resilient the country is."

\section{Integrated Knowledge}

Ranchers need to be able to integrate their knowledge of different factors and balance the needs of different parts of the landscape to maintain the productivity of the land. One rancher integrated knowledge of plant groups and the nutritional needs of animals in the following quote: "If you want grasses, then you should have sheep on because they aren't so hard on them and then in the fall you take the sheep off the forbs and shrubs, and if you want forbs and shrubs to do well you have cows in that pasture. It is a balancing act." Ranchers also spoke of the need to assess, and continually reassess their rangeland based on production, weather, and livestock needs.

Ranchers also talked about the need to integrate social, economic, and ecological factors daily when making decisions and were aware of the ways these factors interacted with each other. Ranchers were concerned that development and fragmentation are leading to the spread of weeds and changed management practices. Although profiting from hunting of increased elk populations, many ranchers were concerned about the negative resource impact of rising elk numbers. One rancher explained, "With the elk a lot of people have seen an increase in weeds. It is an additional vector moving across the landscape." Ranchers described how social and land use changes impact the ability of ranchers to maintain a viable income from ranching. As one rancher stated, "Continuity of agriculture lands will continue to be a big thing for all of us. ... When another one bites the dust there are new neighbors and splitting things off and new fences." In interviews, ranchers demonstrated the ability to integrate complex and multifaceted knowledge of natural and human systems to make decisions.

\section{How Ranchers Learn}

In interviews, ranchers were asked how they learned about ranching. All of the ranchers interviewed (26) mentioned experience as being one of the most important factors in understanding how to manage landscapes. The next most prevalent source of knowledge was informal teachers, including family and friends (13), followed by formal education (9), publications (5), and agency or extension employees (3). When making management decisions, ranchers were split between leaning on personal experience and depending on advice from family members or friends. In the interviews, most of the ranchers reflected on the need to question and experiment with ideas that they read or heard about from neighbors. As one rancher stated, "They all had a reason for doing everything they did. It's just one of those things that you have to make up your own mind about." However, ranchers also expressed deep respect for past managers of the land, suggesting that it is often difficult for them to consider changing techniques or management strategies that have worked in the past. As one rancher stated, "I have neighbors who say my granddaddy did it this way and I am doing it this way."

\section{Knowledge Heterogeneity}

There was wide variation in both the quantity and range of rancher knowledge. Total passages coded served as a proxy for the quantity of knowledge held by each interviewee and varied from a low of 12 to a high of 172 total passages coded in a given interview. Each code referenced a different knowledge type, so we used the total codes referenced in each interview as a proxy for the breadth of knowledge. Total codes referenced in each interview ranged from a low of 9 to a high of 97 . Knowledge was not consistently correlated with either education or experience; however, referrals made by other community members were the best predictor of knowledge quantity and breadth. Despite this overarching trend, several ranchers with few or no referrals had higher numbers of coded quotes than the ranchers with the most referrals, suggesting that some 
knowledgeable ranchers may be missed if informants are chosen solely by number of referrals from community members.

There are several limitations to this method for comparing knowledge between ranchers. First, we were unable to verify each knowledge claim, and therefore coded knowledge claims are not necessarily valid knowledge claims. Second, there is a potential for biased, or inconsistent, coding within interviews. However, inconsistency should be minimal because a single researcher completed all the coding. Finally, interviews may not accurately reflect rancher knowledge because of the limited duration of interviews and potential difficulty communicating knowledge. Ranchers with a similar background to researchers appeared more knowledgeable, but this could be due to common language and perspective that led to greater knowledge sharing. Although these weaknesses exist, this simple quantitative analysis gives a reasonable if rough estimate of the relative depth and breadth of rancher knowledge.

Rancher knowledge is developed through management of livestock and landscapes, and therefore it makes sense that sheep and cattle ranchers would vary in their knowledge and understanding of landscapes. In the interviews sheep ranchers were more aware of diversity and could better identify plant species, reflecting the differences between the nutritional needs of sheep and cows. Sheep ranchers also viewed sagebrush more positively, because of its importance in providing cover during lambing. In addition, they relied on different distribution techniques: although sheep ranchers depend on herders, cattle ranchers were often more aware of other management techniques to distribute livestock. Given different management objectives, ranchers demonstrated wide variation in their understanding of landscape function and their beliefs regarding appropriate management.

\section{Uncertainty and Generalizability: The Limits of Rancher Knowledge}

Although ranchers offered original and valid insights into the workings of natural systems, they often pointed out the limits of their own knowledge. Rangelands are complex and constantly changing systems that require continual reassessments. Many ranchers expressed the difficulty of gauging vegetation change and said things such as "I don't think we pay attention unless it is a great big thing, [but] it is a whole lot of little things that make a big change." Ranchers wondered about the applicability of their knowledge, saying things such as "Time to time I wonder if it is better to be familiar with this little place or if it would be more interesting or beneficial to know a larger piece of country, but I think this is a fairly representative piece of ground." This concern mirrors similar debates among ecologists about the proper scale for analyzing complex systems and the types of generalizations that can be made from limited studies (Peters et al. 2004; Bestelmeyer et al. 2006). Several interviewees also questioned whether ranching and ranchers have been around long enough to realize the potential outcomes of management. One stated, "We haven't lived here long enough to find out what this area can do." We emphasize that these limitations were raised by the ranchers themselves and observe that these perceived limits to local knowledge are not so different from the challenges to generating reliable and generalizable scientific knowledge.

\section{DISCUSSION}

Ranchers in this watershed demonstrate a broad understanding of rangeland ecology including knowledge of plant growth and reproduction, animal behavior, vegetation change, and ecosystem responses to disturbances. However, several important differences between scientific and local understanding of rangeland ecology suggest potential strengths and limitations of local knowledge.

\section{Strengths and Limitations of Rancher Knowledge}

Ranchers are focused on understanding what works in a management context. The majority of knowledge codes referenced managing ecological systems or processes to increase productivity. This is supported by prior studies that showed pastoralist knowledge was more focused on productivity than on maintaining ecosystem processes (Bollig and Schulte 1999). The focus on productivity may make it difficult for ranchers to separate their knowledge from its management context and suggests that there may be concepts or ideas that would never be reached from within an active management framework. However, it also means that ranchers have site-specific applied knowledge, which is often absent from the scientific literature (Millar and Curtis 1999; Oba and Kaitira 2005).

To make decisions, ranchers balance multiple factors (Fernandez-Gimenez 1993) and are aware of the appropriate scale of information for decision making (DeBoer and Prins 1989). On the lands they manage, this includes balancing knowledge of different landscapes, including their productivity, nutrient content, and past management history, to make stocking decisions. On a regional scale, this includes understanding patterns of change such as the increase in exurban development. In interviews, ranchers expressed concern and described the connections between increased subdivision and land fragmentation, and the resulting reduction in weed control on subdivided lands, and increased wildlife populations on intact ranches as habitat is lost to development. Although ranchers perceive the potential repercussions of changed land use and management, they often find themselves facing decisions about subdividing their own land (Rowe et al. 2001). If ranchers' awareness of trends and knowledge of potential trajectories of change could be shared and understood by the community as a whole, dialogue about more sustainable options may arise.

Ranchers are continually assessing the health and productivity of their landscapes. Past research has shown that pastoralists in other regions of the world use local knowledge to understand indicators of change over time and assess sustainability (King et al. 2000; Reed and Dougill 2002; Oba and Kaitira 2005). Ranchers in this study described their use of indicators to gauge short-term land health trends and make decisions about livestock numbers and movements. Many of these indicators are similar to those used in rangeland health assessments (Pellant et al. 2005), including presence of litter, bare ground, and diversity of plant species. Because ranchers develop and use indicators in specific places, they may provide 
insight into the most meaningful, sensitive, and efficient sitespecific indicators of rangeland health.

\section{Constraints to Application of Ranchers' Local Knowledge}

Rancher knowledge is continuously changing with evolving experience. However, adoption of new management practices often does not keep pace with development of new knowledge and awareness of ecological change or management effects. This lag time in applying knowledge may be due to financial and resource limitations, the risk associated with new management techniques, constraining social norms, and ranchers' embedded experience of the ecosystem.

Ranchers gain their knowledge through interactions with the natural world and their peers, rather than by systematically testing hypotheses. Although some ranchers conduct informal management experiments and many ranchers constantly make small adjustments in management to improve livestock and land productivity, a major change in management often represents both significant financial investment and potential economic and ecological risks and uncertainties. In this study financial and resource limitations were the most commonly offered reasons why ranchers did not change management in response to changing knowledge. These findings support prior research on ranchers' adoption of innovations, which also found that operational scale (Didier and Brunson 2004) and socioeconomic status (Coppock and Birkenfeld 1999; Peterson and Coppock 2001) were key factors in the propensity to apply new management practices.

Our research also suggests that knowledge acquisition is a social process facilitated by direct and indirect communication and observation. Our informants in this study, as well as respondents to past rancher surveys, cited peers as one of their most frequent and trusted sources of information (FernandezGimenez et al. 2005). Adoption of new management practices may be limited by what is accepted and practiced by other members of the community. It is likely that social norms strongly influence the adoption of new management practices among ranchers, as has been shown in previous rangeland research on adoption of innovations (Didier and Brunson 2004). The roles of informal social networks and more formal peer learning networks in spreading knowledge and beneficial innovations is an area that deserves greater attention from rangeland social scientists.

Rancher knowledge is being developed and reassessed continuously, and ranchers hold a great deal of valuable information about how vegetation responds to differing environmental conditions and management. This embedded perspective may lead ranchers to believe that they are always seeing fluctuation instead of trends. In our interviews, ranchers often felt limited in their ability to perceive gradual change and attributed this to their continuous contact with the systems they observe and manage. Their knowledge of weather patterns and vegetation responses informs short-term management decisions, but may also make it difficult for ranchers to perceive long-term trends. For instance, although some managers noted possible signs of climate change, few had changed their management practices in response to these indicators. We reason that ranchers' embedded and continuous experience of a landscape may lead to inaction because awareness of and responses to short-term environmental fluctuations and management effects buffer perceptions of gradual, long-term change.

If this is so, it is a potential cause for concern, given recent advances in "resilience thinking" that emphasize the importance of identifying and tracking "slow variables" in rangeland systems (Lyman and Stafford Smith 2004; Briske et al. 2008). Slow variables are indicators of important ecosystem functions that, if significantly altered, may reduce the ability of an ecosystem to recover from severe stress or disturbance (i.e., to lose resilience), potentially leading to a conversion to a totally different kind of system (e.g., a grassland to a shrubland). However, Elkhead ranchers' attention to indicators such as bare ground and erosion suggests that they may be well attuned to important slow variables, and the reason they have not seen long-term trends is that, in fact, there have not been meaningful changes in these slow variables during their time on the land. This interpretation supports ranchers' perceptions that the Elkhead watershed is a resilient system.

\section{Distribution and Variation of Rancher Knowledge}

Referrals were the strongest predictor of knowledge quantity and range and may be the best way to identify the most knowledgeable people in a community. Previous research supports this technique for finding knowledgeable community members (Davis and Wagner 2003; Ballard and Huntsinger 2006), but the interviews also showed that this technique can miss knowledgeable people who are not well known within their communities. Ranchers often can identify the most knowledgeable producers in their own community, suggesting that these knowledge-rich individuals are hubs or nodes in local knowledge networks and could be effective conduits of ecologically sound management practices (Rogers 1962).

\section{Continuity of Knowledge and Viability of Ranching}

A persistent refrain in interviews was a deep concern for the long-term viability of the family ranch. Almost two-thirds of those interviewed had no plan for the future of their ranches, suggesting that the knowledge they maintain through daily contact with the land will end with them. One rancher stated, "I guess the family ranch has gone away. There aren't very many of them. Here, it will never make it. We have passed that stage." Although some ranchers worried about the inevitability of change, others were actively creating a place for themselves in the future. As one rancher stated, "The ranch is a business, not a play toy, and you know what parts are making money and now if agriculture isn't making money but recreation is, I have to change." Facilitating this transition is critical if this active, embedded, and integrative knowledge is to survive. The accumulated knowledge that current ranchers hold may be critical to the sustainability of the next generation of ranches.

\section{CONCLUSIONS}

Local knowledge has often been dismissed or overlooked in range science, management, and land-use planning, but this study suggests several arguments for its inclusion. Interviews showed that ranchers can provide insight and site-specific 
information about the landscapes they inhabit and manage, often areas where long-term monitoring data are unavailable. Given their ongoing assessment of landscapes, ranchers may also help define important local indicators. Increased dialogue between ranchers and scientists may expand our knowledge of sustainable management by highlighting both unique and overlapping contributions of each knowledge type and suggesting specific research questions and management needs ripe for collaborative knowledge creation and problem solving. Rancher knowledge must be understood in the context of working landscapes; however, this need not be a barrier to using it as an information source to understand rangeland ecosystems if ranchers and scientists clearly communicate about the context and purpose of specific types of knowledge.

As one of the first systematic assessments of rancher knowledge, this research offers several insights for designing future studies on rancher knowledge. Our study suggested that community referrals offer an effective way to find the most knowledgeable community members. The process of interviewing also suggested that rancher knowledge is embedded in experience and practice, and it is often difficult for ranchers to communicate their knowledge readily. Using both semistructured interviews and field interviews helped establish rapport and increased the amount and depth of knowledge shared. We hope this exploration of rancher knowledge will inspire future research on rancher knowledge in other contexts so that western landscapes can benefit from a more complete understanding of natural systems and management motivations.

\section{IMPLICATIONS}

Ranchers have a wide range of knowledge related to the management of natural systems that can inform rangeland management and science; however, additional research is needed to further describe and quantify rancher knowledge and identify its applications and limitations. Land management agencies such as the Bureau of Land Management and Forest Service may want to understand what ranchers know about the ecological and management history and dynamics of landscapes under their jurisdiction. Rangeland monitoring efforts on public and private lands may be more effective and efficient if they incorporate indicators commonly used by ranchers. In the past, the Natural Resources Conservation Service and Cooperative Extension have looked at ranchers primarily as an audience to be educated. These agencies may benefit from increased awareness of ranchers' ecological knowledge, including its gaps, to facilitate more targeted and appropriate education efforts and deepen the learning partnership approach that many agents already take. Models of vegetation change, such as state-and-transition models, may also benefit from integration of local knowledge (see Knapp and FernandezGimenez 2009). Knowledge-sharing networks, such as those created with Wisconsin grass farmers (Hassanein 1995), may help ranchers share their knowledge, review and ground truth scientific findings, and collectively interpret patterns of change. Such networks could also potentially expand and strengthen existing social networks that are critical for knowledge transfer and social sustainability in ranching communities.

\section{ACKNOWLEDGMENTS}

We would like to express sincere gratitude to the ranchers, farmers, residents, and agency employees who generously shared their time and knowledge as part of this research project.

\section{LITERATURE CITED}

Agrawal, A. 1993. Mobility and cooperation among nomadic shepherds: the case of the Raikas. Human Ecology 21:261-279.

Agrawal, A. 1995. Indigenous and scientific knowledge. Indigenous Knowledge and Development Monitor 3(3). Available at: http://www.nuffic.nl/ciran/ikdm/ 3-3/articles. Accessed 2 October 2009.

Arnold, J., and M. Fernandez-Gimenez. 2003. Collaborative development and qualitative assessment of a rangeland management curriculum on the Tohono O'odham nation. Proceedings from the VIIth International Rangelands Congress; 26 July-1 August 2003; Durban, South Africa. p. 1824-1826.

Ballard, H., and L. Huntsinger. 2006. Salal harvester local ecological knowledge, harvest practices and under-story management on the Olympic Peninsula, Washington. Human Ecology 34:529-547.

Belgrave, B. R., P. C. Watt, and J. L. Brock. 1990. A survey of farmer knowledge and use of pasture cultivars in New Zealand. New Zealand Journal of Agricultural Research 33:199-211.

Bestelmeyer, B. T., D. A. Trujillo, A. J. Tugel, and K. M. Havstad. 2006. A multi-scale classification of vegetation dynamics in arid lands: what is the right scale for models, monitoring, and restoration? Journal of Arid Environments 65:296-318.

Bollig, M., And A. Schulte. 1999. Environmental change and pastoral perceptions: degradation and indigenous knowledge in two African pastoral communities. Human Ecology 27:493-514.

Briske, D. D., B. T. Bestelmeyer, T. K. Stringham, and P. L. Shaver. 2008. Recommendations for development of resilience-based state-and-transition models. Rangeland Ecology and Management 61:359-367.

Carr, A. 2004. Why do we all need community science? Society and Natural Resources 17:841-849.

Colding, J., AND C. FolkE. 2001. Social taboos: "invisible" systems of local resource management and biological conservation. Ecological Applications 11: $584-600$.

ConkLIN, H. C. 1954. An ethnoecological approach to shifting agriculture. Transactions of the New York Academy of Sciences 17:133-142.

Conley, J. L., M. Fernandez-Gimenez, G. B. Ruyle, and M. Brunson. 2007. Forest service grazing permittee perceptions of the Endangered Species Act in southeastern Arizona. Rangeland Ecology and Management 60:136-145.

Coppock, D., And A. BiRKENFeld. 1999. Use of livestock and range management practices in Utah. Journal of Range Management 52(1):7-18.

Dalal-Clayton, B., and D. Dent. 2001. Knowledge of the land: land resources information and its use in rural development. Oxford, United Kingdom: Oxford University Press. $428 \mathrm{p}$.

Daniels, S. E., and G. B. Walker. 2001. Working through environmental conflict. Westport, CT, USA: Praeger. 293 p.

Davis, A., AND J. R. WAgner. 2003. Who knows? On the importance of identifying "experts" when researching local ecological knowledge. Human Ecology 31:463-487.

DavIS, D. K. 2005. Indigenous knowledge and the desertification debate: problematising expert knowledge in North Africa. Geoforum 36:509-524.

Deboer, W. F., and H. T. Prins. 1989. Decisions of cattle herdsmen in Burkina Faso and optimal foraging models. Human Ecology 17:445-464.

Desta, S., And D. L. Coppock. 2004. Pastoralism under pressure: tracking system change in southern Ethiopia. Human Ecology 32:465-486.

Dewalt, B. R. 1994. Using indigenous knowledge to improve agriculture and natural resource management. Human Organization 53:123-131.

DidIER, E. A., AND M. BRUnson. 2004. Adoption of range management innovations by Utah ranchers. Journal of Range Management 57:330-336. 
EluICKson, R. C. 1991. Order without law: how neighbors settle disputes. Cambridge, MA, USA: Harvard University Press. 302 p.

Fazey, I., K. Proust, B. Newell, B. Johnson, and J. Fazey. 2006. Eliciting the implicit knowledge and perceptions of on-ground conservation managers of the Macquarie marshes. Ecology and Society 11:25(online). Available at: http:// www.ecologyandsociety.org/vol11/iss1/art25/. Accessed 2 October 2009.

Fernandez-Gimenez, M. 1993. The role of ecological perception in indigenous resource management: a case study from the Mongolian forest-steppe. Nomadic Peoples 33:31-46.

Fernandez-Gimenez, M. 2000. The role of Mongolian nomadic pastoralists' ecological knowledge in rangeland management. Ecological Applications 10:1318-1326.

Fernandez-Gimenez, M. E., G. Ruyle, and S. J. McClaran. 2005. An evaluation of Arizona cooperative extension's rangeland monitoring program. Rangeland Ecology and Management 58:89-98.

Garden, D. L., P. M. Dowling, D. A. Eddy, And H. I. Nicol. 2000. A survey of farms on the central, southern and monaro tablelands of New South Wales: management practices, farmer knowledge of native grasses, and extent of native grass areas. Australian Journal of Experimental Agriculture 40:1081-1088.

GILL, N. 2005. Life and death in Australian 'heartlands': pastoralism, ecology and rethinking of the outback. Journal of Rural Studies 21:39-53.

GrigsBy, T. L. 1980. Today's riders of the purple sage: symbols, values and the cowboy myth. Rangelands 2(3):93-96.

HASSANEIN, N. 1995. Where the grass grows again: knowledge exchange in the sustainable agriculture movement. Rural Sociology 60(4):721-740.

Heinz Center. 2002. The state of the nation's ecosystems: measuring the lands, waters and living resources of the United States. Cambridge, United Kingdom: The Press Syndicate of the University of Cambridge. 292 p. Available at: http:// www.heinzctr.org/ecosystems/2002report/index.html. Accessed 2 October 2009.

High Plains Regional Climate Center. 2008. Climate summary for Hayden, Colorado. Available at: http://www.hprcc.unl.edu/index.php. Accessed 8 January 2008.

HudAK, A. T. 1999. Rangeland management in South Africa: failure to apply ecological knowledge. Human Ecology 27:55-78.

Huntington, H. P. 1997. Observations on the utility of the semi-structured interview. Arctic 51(3):237-242.

Huntington, H. P. 2000. Using traditional ecological knowledge in science: methods and applications. Ecological Applications 10:1270-1274.

Johnson, N. L., N. LILJA, AND J. A. AshBy. 2003. Measuring the impact of user participation in agricultural and natural resource management. Agricultural Systems 78:287-306.

KelLy, D. 2001. Community participation in rangeland management. Gatton, Queensland: Rural Industries Research and Development Corporation. $132 \mathrm{p}$

King, C., J. Gunton, D. Freebairn, J. Coutts, and I. WebB. 2000. The sustainability indicator industry: where to from here? Australian Journal of Experimental Agriculture 40:631-642.

Knapp, C. N., and M. Fernandez-Gimenez. 2008. Knowing the land: a review of local knowledge revealed in ranch memoirs. Rangeland Ecology and Management 61:148-155.

Knapp, C. N., And M. Fernandez-Gimenez. 2009. Understanding change: integrating rancher knowledge into state-and-transition models in northwest Colorado. Rangeland Ecology and Management 62:510-521.

Kreuter, U. P., H. E. Amestoy, D. N. Ueckert, and W. A. McGinty. 2001. Adoption of brush busters: results of Texas county extension survey. Journal of Range Management 54:630-639.

Kreuter, U. P., J. B. Woodard, C. A. Taylor, and W. R. Teague. 2008. Perceptions of Texas landowners regarding fire and its use. Rangeland Ecology and Management 61:456-464.

KROLL, T., AND A. S. KRUGER. 1998. Closing the gap: bringing communal farmers and service institutions together for livestock and rangeland development. Journal of Arid Environments 39:315-323.

KuznaR, L. A. 1999. Traditional pastoralism and development: a comparison of Aymara and Navajo grazing ecology. In: T. L. Gragson and B. Blout [EDS.]. Ethnoecology: knowledge, resources and rights. Atlanta, GA, USA: University of Georgia Press. 163 p.
Lynam, T. J., AND M. Stafford Smith. 2004. Monitoring in a complex world-seeking slow variables, a scaled focus, and speedier learning. African Journal of Range and Forage Science 21(2):69-78.

Mackinson, S. 2001. Integrating local and scientific knowledge: an example in fisheries science. Environmental Management 27:533-545.

MannieR, D. J., AND N. T. HobBs. 2006. Large herbivores influence the composition and diversity of shrub-steppe communities in the Rocky Mountains, USA. Oecologia 146:641-651.

MARTEN, G. G. 1986. Traditional agriculture in Southeast Asia. Boulder, CO, USA: Westview Press. $358 \mathrm{p}$.

Merriam-Webster Online Dictionary. 2008. Definition of pastoralist. Available at: http://www.merriam-webster.com/dictionary/pastoralist. Accessed 17 July 2008.

Metz, C. 2004. Changing times: ranching in Routt County. Series of articles in The Steamboat Pilot; 25 July 2004, 1, 8, 15, 22 August 2009; Steamboat Springs, CO, USA. p. 1-4AA

MILlaR, J., AND A. CURTIs. 1999. Challenging the boundaries of local and scientific knowledge in Australia: opportunities for social learning in managing temperate upland pastures. Agriculture and Human Values 16:389-399.

Moore, H. L. 1996. The future of anthropological knowledge. London, United Kingdom: Routledge. $175 \mathrm{p}$

MorRIS, C. 2006. Negotiating the boundary between state-led and farmer approaches to knowing nature. Geoforum 37:113-127.

Netting, R. 1981. Balancing on an Alp. New York, NY, USA: Cambridge University Press. $278 p$

Neuman, W. L. 2003. Social research methods: qualitative and quantitative approaches. Boston, MA, USA: Allyn and Bacon. 584 p.

NiamiR, M. 1995. Indigenous systems of natural resource management among pastoralists of arid and semi-arid Africa. In: D. M. Warren, L. J. Slikkerveen, and D. Brokensha [EDS.]. The cultural nature of development. London, United Kingdom: Intermediate Technology Publications. p. 245-257.

NVIVO [COMPUTER PRogram]. 1999-2000. QSR revision 1.2. Victoria, Australia: QSR International.

OBA, G., AND L. M. KaITIRA. 2005. Herder knowledge of landscape assessments in arid rangelands in northern Tanzania. Journal of Arid Environments 66:168-186

Pellant, M., D. Pyke, P. Shaver, and J. E. Herrick. 2005. Interpreting indicators of rangeland health. Denver, CO, USA: Bureau of Land Management. $122 \mathrm{p}$.

Peters, D., R. A. Pielke, B. T. Bestelmeyer, C. D. Allen, S. Munson-Mcgee, and K. M. HAVSTAD. 2004. Cross-scale interactions, non-linearities, and forecasting catastrophic events. Proceedings of the National Academy of Sciences 101(42):15130-15135.

Peterson, R., and D. L. Coppock. 2001. Economics and demographics constrain investment in Utah private grazing lands. Journal of Range Management 54(2):106-113.

Pierotti, R., and D. Wildcat. 2000. Traditional ecological knowledge: the third alternative. Ecological Applications 10:1333-1340.

Read, P. 1996. Returning to nothing. Cambridge, United Kingdom: Cambridge University Press. $240 \mathrm{p}$

Reed, M. S., and A. J. Dougill. 2002. Participatory selection process for indicators of rangeland condition in the Kalahari. Geographical Journal 168:224-234.

RoBA, H. G., AND G. OBA. 2009. Community participatory landscape classification and biodiversity assessment and monitoring of grazing lands in northern Kenya. Journal of Environmental Management 90(2):673-682.

Rogers, E. M. 1962. Diffusion of innovation. New York, NY, USA: Free Press. $512 \mathrm{p}$.

Rowan, R. C., H. W. Ladewig, and L. D. White. 1994. Perceptions vs. recommendations: a rangeland decision-making dilemma. Journal of Range Management 47:344-348.

Rowe, H. I., E. T. Bartlett, and L. Swanson. 2001. Ranching motivations in 2 Colorado counties. Journal of Range Management 54:314-321.

Saltiel, J., and L. R. Irby. 1998. Perceptions of game damage in Montana by resource agency personnel and agricultural producers. Wildlife Society Bulletin 26:84-91. 
Smidt, N. W., and L. Brimer. 2005. The use of herbs in pastures: an interview survey among bio-dynamic and organic farmers with dairy cattle. Agriculture and Human Values 22:355-363.

SPEnCER, P. 2004. Keeping tradition in good repair: the evolution of indigenous knowledge and the dilemma of development among pastoralists. In: A. Bicker, P. Sillitoe, and J. Pottier [EDs.]. Development and local knowledge: new approaches to issues in natural resources management, conservation and agriculture. London, United Kingdom: Routledge. p. 202218.

Strang, V. 1997. Uncommon ground. Oxford, United Kingdom: Berg. 308 p.

Thrupp, L. A. 1989. Legimitizing local knowledge. Agriculture and Human Values $6(3): 13-24$.

US Census Bureau. 2008. Routt and Moffat county quick facts. Available at: www. quickfacts.census.gov. Accessed 25 January 2008.
US Forest Service. 2008. About rangelands. Available at: http://www.fs.fed.us/ rangelands/whoweare/index.shtml. Accessed 18 July 2008.

US Forest SERVICE. 2009. Routt National Forest land and resource management plan: final environmental impact statement. Appendix D. Available at: http:// www.fs.fed.us/r2/mbr/projects/forestplans/routt/index.shtml. Accessed 15 June 2009.

WeSt, N. E. 2003. History of rangeland monitoring in the U.S.A. Arid Land Research and Management 17:495-545.

WhYTE, W. F. 1982. Interviewing in field research. In: R. G. Burgess [ED.]. Field research: a sourcebook and field manual. London, United Kingdom: Allen and Unwin. p. 111-122.

Yung, L., AND J. M. Belsky. 2007. Private property rights and community goods: negotiating landowner cooperation amid changing ownership on the Rocky Mountain Front. Society and Natural Resources 20(8):689-703. 